\title{
Inflation and Recession Cycle: Impacts over Global Economies and Markets
}

\author{
${ }^{1}$ Dr. Esha Jain, ${ }^{2} \mathrm{Mr}$. Ashank Yadav \\ ${ }^{I}$ GD Goenka University, Gurgaon, India. \\ ${ }^{2}$ GD Goenka University, Gurgaon, India.
}

\begin{abstract}
Cash - in savings accounts, short-term CDs or money market deposits - is great for an emergency fund. But to fulfill a long-term investment goal like funding your retirement, consider buying stocks. The more distant your financial target, the longer inflation will gnaw at the purchasing power of your money. - Suze Orman

The purpose of this study is to understand rise in inflation and emergence of recession after inflation. The major causes for the occurrences of the two economic situations. Further is to relate the global economies with the concepts of inflation and recession and to study how and what changes and shifts inflation to recession. The major impacts they have over the economies and the markets. The study is to understand the two big parts of the economic cycle or boom-bust cycle globally.
\end{abstract}

Keywords-Boom Burst cycle, Economic cycle,Inflation, Recession.

\section{Inflation vs. Recession}

\section{Introduction}

A recession is when the economy stops growing and goes into reverse. Instead of adding new jobs, there are fewer jobs. Instead of companies making more money than the year before, they make less. Consumers spend less because more of them are out of work. Companies sell even less stuff, make less money and around it goes. Recessions correct themselves when interest rates go down. Rates go down when there's less demand for borrowing, which is what happens in a recession. Consumers use their credit cards less and businesses don't need to borrow to build a new plant or open a new office to meet new demand. With lower demand for loans, lenders lower interest rates. Think of it as cutting the price of money and having a big sale. Those lower rates make it easier to borrow and spend. And as consumers and businesses borrow and spend, the economy gradually starts expanding again.

Inflation is a state of an increase in prices. There are several causes, but it typically happens when an economy gets going too fast. Everyone is so flush with cash and credit that consumers spend freely and businesses expand rapidly. When they do, they're competing for the same goods and labor. If supplies are limited and demand stays strong then the prices go up. If inflation gets started, it can be hard to control. As prices rise, consumers demand higher wages from their employers, who pass along the higher labor cost by raising their prices for goods and services. That makes it harder for consumers to make ends meet, so they ask for more money, etc. Round and round it goes.

\section{Inflation}

Inflation is a sustained increase of the general price level of goods and services in an economy over a period of time. Inflation is the rate at which the general level of prices for goods and services is rising, and, subsequently, purchasing power is falling. Central banks attempt to stop severe inflation, along with severe deflation, in an attempt to keep the excessive growth of prices to a minimum.Inflation affects an economy positively as well as negatively. Negative effects of inflation include an increase in the opportunity cost of holding money, uncertainty over future inflation which may discourage investment and savings, and if inflation were rapid enough, shortages of goods as consumers begin hoarding out of concern that prices will increase in the future. Positive effects include ensuring that central banks can adjust real interest rates to prevent severe impacts of recessions, and encouraging investment in non-monetary capital projects. The high rates of inflation and hyperinflation are caused by an excessive growth of the money, though, money supply growth does not necessarily cause inflation supply always.

Inflation is a sign that an economy is growing. In some situations, little inflation (or even deflation) can be just as bad as high inflation. The lack of inflation may be an indication that the economy is weakening.

Terminologies related to inflation- 
- Deflation is when the general level of prices is falling. This is the opposite of inflation.

- Hyperinflation is unusually rapid inflation. In extreme cases, this can lead to the breakdown of a nation's monetary system. One of the most notable examples of hyperinflation occurred in Germany in 1923 , when prices rose $2,500 \%$ in one month!

- Stagflation is the combination of high unemployment and economic stagnation with inflation. This happened in industrialized countries during the 1970s, when a bad economy was combined with OPEC raising oil prices.

\section{Causes of Inflation}

1. Demand-Pull Inflation- This theory can be summarized as "too much money chasing too few goods". In other words, if demand is growing faster than supply, prices will increase. This usually occurs in growing economies.

2. Cost-Push Inflation- When companies' costs go up, they need to increase prices to maintain their profit margins. Increased costs can include things such as wages, taxes, or increased costs of imports.

\section{Impacts Of Inflation}

Most of the economists thinks inflation is evil, but it isn't necessarily so. Inflation affects different people in different ways. It also depends on whether inflation is anticipated or unanticipated. If the inflation rate corresponds to what the majority of people are expecting (anticipated inflation), then we can compensate and the cost isn't high. For example, banks can vary their interest rates and workers can negotiate contracts that include automatic wage hikes as the price level goes up.

\section{Economic problems which arise in situation of unanticipated inflation-}

- Creditors lose and debtors gain if the lender does not anticipate inflation correctly. For those who borrow, this is similar to getting an interest-free loan.

- Uncertainty about what will happen next makes corporations and consumers less likely to spend. This hurts economic output in the long run.

- People living off a fixed-income, such as retirees, see a decline in their purchasing power and, consequently, their standard of living.

- The entire economy must absorb reprising costs ("menu costs") as price lists, labels, menus and more have to be updated.

- If the inflation rate is greater than that of other countries, domestic products become less competitive.

\section{Impact Over Economies And Markets}

Inflation is when you pay fifteen dollars for the ten-dollar haircut you used to get for five dollars when you had hair. - Sam Ewing

The main examples of the countries hit inflation-

Venezuela is the fifth largest member of OPEC as measured by the production of oil. It derives over $50 \%$ of its GDP from petroleum exports which represents about 95\% of total exports. From the 1950s to the early 1980s, Venezuela had the strongest economy in South America. Today, it's one of the most repressive regimes in the world, especially with regards to property rights. Owners of private property have regularly had their property confiscated by the government, often without compensation. This practice is known as expropriation or eminent domain. Although this is entirely legal, it has been greatly abused in Venezuela.

Venezuela has a current inflation rate of $57.30 \%$. The country has been suffering from inflation for many years. During the period from 1973 to 2014, it's been as high as $115.18 \%$ and as low as $3.22 \%$. The annual rate has exceeded 100\% during two episodes. The first occurred in June 1989 when it hit $103.29 \%$. The second time, inflation remained above $100 \%$ for seven months from July 1996 (108.13\%) to January 1997 (103.24\%). Currently, it's on the rise again and many economists believe it could breech the century mark once again and hyperinflation will ensue. What's particularly disturbing for the citizens of Venezuela is that, after the mid1980 s, the annual inflation rate has been above $20 \%$ more often than not.

Iran has an inflation rate of $19.70 \%$ which ranks second behind Venezuela. The highest rate Iran has had was 59.02\% in May 1995. In fact, from April 1995 through January 1996, Iran's inflation rate remained above 50\% with the exception of October 1995 when it fell to 46.17\%. A high, sustained rate of inflation is trouble for any economy. Iran's economy is contracting as its GDP is $-5.50 \%$ over the trailing 12 month period. In essence, the Iranian economy is in recession.

Argentina's inflation rate seems rather benign in comparison to the previous countries mentioned. Currently, it is $10.90 \%$. However, Argentina's highest annual rate of inflation was a staggering 20,262\% in the 12 month period ending April 1990. That definitely constitutes hyperinflation. To translate using U.S. dollars, an item which cost \$1 in May 1989 would have cost \$203.62 one year later. Argentina was in a depression from late

DOI: $10.9790 / 5933-0802020105 \quad$ www.iosrjournals.org $\quad 2 \mid$ Page


1998 to 2002. During this period, GDP bottomed at $-16.3 \%$ in the first half of 2002. This depression was preceded by several rounds of economic contraction from 1974 to 1990. Today, Argentina's economy is doing better with GDP of $5.50 \%$ and a slightly elevated unemployment rate of $6.40 \%$. However, inflation is still too high and the country's short-term money market rate is also elevated at $14.73 \%$. Even so, at least inflation is lower than its interest rate, leaving investors with a positive real return on their money.

\section{Recession}

Economic recession is a period of general economic decline and is typically accompanied by a drop in the stock market, an increase in unemployment, and a decline in the housing market. Generally, a recession is less severe than a depression. Many factors contribute to an economy's fall into a recession, but the major cause is inflation. Inflation refers to a general rise in the prices of goods and services over a period of time. The higher the rate of inflation, the smaller the percentage of goods and services that can be purchased with the same amount of money. Inflation can happen for reasons as varied as increased production costs, higher energy costs and national debt.

\section{Factors Causing Recessions}

1. Increased Inflation- Inflation is one of the major reason for the cause of recession to occur in an economy effecting its markets.Inflation refers to a general rise in the prices of goods and services over a period. As inflation increases, the percentage of goods and services that can be purchased with the same amount of money decreases.

2. High Interest Rate- High interest rates are a cause of recession because it limits liquidity, or the amount of money available to invest.

3. Reduced Consumer Confidence- If consumers believe the economy is bad, they are less likely to spend money. Consumer confidence is psychological but can have a real impact on any economy.

4. Reduced Real Wages- Real wages refers to wages that have been adjusted for inflation. Falling real wages means that a worker's paycheck is not keeping up with inflation. The worker might be making the same amount of money but his purchasing power has been reduced.

\section{Economic Recession And Its Impact Over Gross Domestic Product}

An economic recession is typically defined as a decline in Gross Domestic Product (GDP) for two or more consecutive quarters. GDP is the market value of all goods and services produced within a country in a given period of time. An example of one type of GDP would be the value of all the automobiles produced within the India for one year. GDP only takes into account new products that have been manufactured. Therefore, if a preowned car lot were selling pre-owned cars they would not be included in the GDP calculation.

\section{Impact Over Economies And Markets}

The financial crisis of 2007-2008, also known as the Global Financial Crisis and 2008 financial crisis, is considered by many economists to have been the worst financial crisis since the Great Depression of the 1930s. It threatened the total collapse of large financial institutions, which was prevented by the bailout of banks by national governments, but stock markets still dropped worldwide. In many areas, the housing market also suffered, resulting in evictions, foreclosures and prolonged unemployment. The crisis played a significant role in the failure of key businesses, declines in consumer wealth estimated in trillions of U.S. dollars, and a downturn in economic activity leading to the 2008-2012 global recession and contributing to the European sovereign-debt crisis. The active phase of the crisis, which manifested as a liquidity crisis, can be dated from August 9, 2007, when BNP Paribas terminated withdrawals from three hedge funds citing "a complete evaporation of liquidity".

Recently Russian economy is falling into the trap of recession, it is noted after the crisis of 2007-2009, the Russian economy did not showed any significant growth. Russia's economy has taken a series of heavy hits in the past few months, and now it seems to be in the midst of a perfect storm. The country depends heavily on oil exports, and prices are down sharply. The Russian currency is losing value fast. And U.S. and European sanctions, imposed after Russia's takeover of Crimea, are biting hard."The economy is close to recession," has been said by Oleg Zasov, the head of forecasting at the economy ministry, according to Russian news agencies. The Russian ministry held its forecast at growth of just 0.5 percent this year, compared with 1.3 percent in 2013. In July 2014, it had defiantly predicted growth of 1.0 percent when the West imposed its first sectorial sanctions over Moscow's support for pro-Russian rebels fighting in eastern Ukraine. But it has now slashed its forecast for 2015 in half, also to 1.0 percent.

Fear of global recession in 2015 has again raised four years after the end of the Great Recession, it looks as if the U.S. economy might finally be poised for breakout growth. Monthly job growth in 2014 is, on average, 
faster than at any point since the financial crisis. Overall economic growth appears to picking up too, with real GDP growing by more than $4 \%$ in the second quarter of this year, and many economists predicting higher overall growth compared to last year. But news outside the U.S. is not so good. European economies are still battling depression-era levels of unemployment and the threat of deflation. And emerging economies, like China, are having trouble maintaining the kind of growth they have become accustomed to in recent years. The most recent readings out of China have the world's second-largest economy growing at roughly $7.5 \%$ per year, down from the $10 \%$ growth it averaged for two decades before its economy began to slow in 2012 . And this pattern holds for other emerging economies like Brazil and Russia. Economists are calling for a $65 \%$ chance that there will be a global recession by the end of 2015, based on the simple fact that emerging markets have continued to invest in an export infrastructure to sell goods to the West that it no longer has the wherewithal to buy.

Recently Japan is alarmed for its falling GDP which is resulting in coming recession. The country of Japan has been facing a recession due to many occurring circumstances that have caused Japan's economy to slowly spiral down. On December 8, 2009; Japan's government reached an agreement regarding the financial crisis that the country is facing and has chosen to put a stimulus package into action. The stimulus package that Japan has put together will have a budget of 7.2 trillion yen to help stimulate the country's decreased employment rate, give incentives for energy efficient products, and help give loans to business owners.In May 2009, the Japanese government approved a 2 trillion yen stimulus package for weaker and less stable Japanese corporations. In Japan, it is common for the government to assist weaker companies, versus less-common systems such as the American corporate bailout.

On $8^{\text {th }}$ December 2014 the news sources including BBC and Bloomberg say that Japan's recession was deeper than initially estimated as company investment unexpectedly shrank. This was a blow to Prime Minister Shinzo Abe as he campaigns for re-election on his economic credentials.High quality global journalism requires investment. Please share this article with others using the link below, do not cut $\&$ paste the article. According to the Cabinet Office's first estimate three weeks back from $8^{\text {th }}$ December 2014, gross domestic product shrank at an annualized rate of 1.6 per cent between July and September, amid big cuts in companies' inventories and falls in private investment.It also shrank $0.5 \%$ on a quarterly basis, compared with an initial estimate of $0.4 \%$, data showed. A big fall in business spending plunged the economy into a deeper recession. The revised figures, which come just days before Japan's national elections, showed that business spending dipped by $0.4 \%$ from the previous quarter, instead of the $0.2 \%$ estimated in the preliminary reading.The world's third largest economy unexpectedly fell into a technical recession after shrinking for the second consecutive quarter in July to September. It had contracted $7.3 \%$ in the second quarter, which was the biggest fall since the March 2011 earthquake and tsunami. An increase in the country's sales tax, which was first raised in April from 5\% to 8\%, had hit growth in the second quarter and still appeared to be having an impact on the economy. The dire data had led Prime Minister Shinzo Abe to call a widely-anticipated snap election last month, to seek a mandate to delay an increase in the tax to $10 \%$, scheduled for 2015 . The tax increase was legislated by the previous government in 2012 to curb Japan's huge public debt, which is the highest among developed nations.

\section{Conclusion}

With the conclusion of the study it is now understood that high inflation is very destructive and ultimately leads to deformation of an economy. On the other hand in the situation of recession the economies get stagnant with no jobs and no monetary flows. Though these concepts are from boom-bust economic cycles but still relate each other closely. Talking about the inflation hit countries, Venezuela is in the throes of a serious inflationary period. Iran's economy is in recession. Argentina seems to be in the best position of the three, but has a few challenges. Venezuela and Iran have intrusive government policies which hinder private sector growth. Until these nations create a more open and free economic environment which will attract outside capital and business, they will likely continue to suffer economically. Meanwhile, many citizens are forced to live in poverty and because they're poor, they cannot afford to relocate, something the wealthy can easily do. High inflation can be worse than recession. Everything costs more every year, so if you're on a fixed income, you have less and less buying power. And inflation is terrible for savings and investments. If you have $\$ 1,000$ in the bank today, it buys less tomorrow and even less next month.Talking about recession, as already included example of the financial crisis of 2007-2008, also known as the Global Financial Crisis had taken economies of Europe and US in its fate, though there was impact over India as well as other Asian countries for a little period of time. The country which is fearing recession recently is Russia (by the data updated by Russian authorities) as well as Japan just entering to severe stage, though the world is again fearing of global recession which could again take over the economies in 2015. 


\section{REFERENCES}

[1]. http://economictimes.indiatimes.com/definition/inflation

[2]. http://education-portal.com/academy/lesson/what-is-economic-recession-definition-causes-effects.html

[3]. http://fortune.com/2014/10/28/global-recession-us-europe-china/

[4]. http://www.afr.com/p/world/russia_sees_recession_as_sanctions_5zAA81xRiv8mY1YmJSOEIJ

[5]. http://www.bbc.com/news/business-30373560

[6]. http://www.bloomberg.com/news/2014-12-07/japan-recession-deeper-than-first-thought-as-abe-faceselection.html

[7]. http://www.britannica.com/EBchecked/topic/1661642/The-Great-Recession-of-2008-09-Year-InReview-2009

[8]. http://Www.businessinsider.com/afp-sanctions-hit-russian-economy-nears-recession-2014-8?IR=T

[9]. http://www.economist.com/news/europe/21621877-wests-sanctions-are-hitting-contracting-economyedge-recession

[10]. http://www.forbes.com/sites/mikepatton/2014/05/09/the-three-countries-with-the-highest-inflation/2/

[11]. http://www.investopedia.com/ask/answers/08/cause-of-recession.asp

[12]. http://www.investopedia.com/terms/i/inflation.asp

[13]. http://www.nbcnews.com/id/20893121/ns/business-answer_desk/t/whats-deal-recession-inflation/

[14]. http://www.npr.org/blogs/parallels/2014/12/03/368143679/sanctions-and-low-oil-prices-push-russiaseconomy-toward-recession

[15]. http://www.sjsu.edu/faculty/watkins/globalrec.htm

[16]. http://www.theguardian.com/world/2014/nov/07/rouble-crashes-russian-economy-brink-recessioncurrency

[17]. http://www.tradingeconomics.com/country-list/inflation-rate 